\title{
KUALITAS AIR PADA SUMBER MATA AIR DI PURA TAMAN DESA SANGGALANGIT SEBAGAI SUMBER AIR MINUM BERBASIS METODE STORET
}

\author{
Muhamad Faisal ${ }^{1}$, Dewa Made Atmaja ${ }^{2 *}$ \\ Prodi Pendidikan Geografi, Universitas Pendidikan Ganesha, Indonesia
}

\section{A R T I C L E I N F O}

\section{Article history:}

Received 09 April 2019

Received in revised form 6 Mei 2019

Accepted 12 Juni 2019

Available online 31 Agustus 2019

\section{Kata Kunci:}

Kualitas air

Sumber Air Minum

Keywords:

Water Quality

Drinking Water Sources

\begin{abstract}
A B S T R A K
Penelitian ini dilaksanakan di Desa Sanggalangit, Kecamatan Gerokgak dengan tujuan: 1) menganalisis kualitas air pada sumber mata air di Pura Taman Desa Sanggalangit sebagai sumber air minum berbasis metode storet, 2) mendeskripsikan kelayakan air sebagai sumber air minum berbasis metode storet, 3) membandingkan kualitas air pada tahun 2001 dan pada tahun 2019. Pengumpulan data menggunakan observasi, metode pencatatan dokumen, dan metode analisis laboratorium. Data yang diperoleh dianalisis secara deskriptif kualitatif. Hasil penelitian menunjukan 1) Ditinjau dari sifat fisik dan kimia memenuhi standar baku mutu air mium sedangkan dari sifat biologi mengalami pencemaran ringan. 2) Masih layak untuk dikonsumsi tetapi perlu pengolahan terlebih dahulu dan 3) Perbandingan kualitas air di Pura Taman pada tahun 2001 dan pada tahun 2019 ditinjau dari sifat fisik masih sama, dari sifat kimia mengalami perubahan dan dari segi biologi mengalami penurunan.
\end{abstract}

\section{A B S T R A C T}

This research was conducted in Sanggalangit Village, Gerokgak Subdistrict with the aim of: 1) analyzing air quality at the spring source in Sanggalangit Village Park Temple as a source of drinking water based on storet method, 2) describing the feasibility of water as a source drinking water based on the storet method, 3) comparing air quality at spring sources in 2001 and in 2019. Data collection uses observation, document recording methods, and Laboratory Analysis Methods. The data obtained was completed in a qualitative descriptive manner. The results showed 1) The results of the analysis in terms of physical and chemical properties meet the standard of quality of the water while the biological properties improve mild pollution. 2) The feasibility is still feasible to buy but needs to be processed first and 3) Comparison of air quality in 2001 and in 2019 in terms of the same material, from changing chemical properties and from biology.

\footnotetext{
* Corresponding author.

E-mail addresses: faisalmuhamad680@gmail.com, made.atmaja@undiksha.ac.id
} 



\section{Pendahuluan}

Air merupakan bahan alam yang diperlukan untuk kehidupan manusia, hewan dan tanaman menggunakan air yaitu sebagai media pengangkutan zat-zat makanan, juga merupakan sumber energi serta berbagai keperluan lainnya (Arsyad, 1989). Sehingga air menjadi sumber daya alam yang memenuhi kebutuhan orang banyak yang perlu dilindungi agar tetap dapat bermanfaat bagi hidup dan kehidupan manusia serta makhluk hidup lainnya di bumi. Persyaratan yang dilakukan untuk menjaga atau pencapai standar kualitas air sehingga dapat dimanfaatkan secara berkelanjutan sesuai dengan tingkat mutu air yang diinginkan, maka perlu upaya pelestarian dan pengendalian. Air sebagai komponen lingkungan hidup akan dipengaruhi oleh komponen lainnya. Air yang kualitasnya buruk akan mengakibatkan kondisi kesehatan dan keselamatan manusia serta kehidupan makhluk hidup lainnya. Penurunan kualitas air akan menurunkan daya guna, hasil guna, produktivitas, daya dukung dan daya tampung dari sumber daya air yang pada akhirnya akan menurunkan kekayaan sumber daya alam (natural resources depletion). Komponen sumber daya alam yang sangat penting maka harus dipergunakan semaksimal mungkin bagi kemakmuran rakyat.

Hal ini berarti bahwa pengggunaan air untuk berbagai manfaat dan kepentingan harus dilakukan secara bijaksana dengan memperhitungkan kepentingan generasi sekarang dan masa depan. Usaha atau kegiatan manusia memerlukan air yang berdaya guna, tetapi di lain pihak berpotensi menimbulkan dampak negatif, antara lain berupa pencemaran yang dapat mengancam ketersediaan air, daya guna, daya dukung, daya tampung, dan produktivitasnya Agar air dapat bermanfaat secara lestari dan pembangunan dapat berkelajutan, maka dalam pelaksanaan pembangunan perlu dilakukan pengelolaan kualitas air dan pengendalian pencemaran air. Dampak negatif dari pencemaran air mempunyai nilai (biaya) ekonomis di samping nilai ekologis, dan sosial budaya. Upaya pemulihan kondisi air yang tercemar, bagaimanapun akan memerlukan biaya yang mungkin lebih besar bila dibandingkan dengan nilai kemanfaatan finansial dari kegiatan yang menyebabkan pencemarannya.

Berdasarkan definisinya, pencemaran air yang diindikasikan dengan turunnya kualitas air sampai ke tingkat tertentu akan menyebabkan air tidak dapat sesuai dengan peruntukannya. Penetapan baku mutu air dengan pendekatan golongan peruntukkan perlu disesuaikan dengan menerapkan pendekatan klasifikasi kualitas air (kelas air), sehingga dapat dihitung berapa beban zat pencemar yang diterima oleh air. Kualitas air yang baik akan sesuai dengan peraturan yang dikeluarkan oleh pemerintah tersebut dengan kadar (konsentrasi) maksimum yang diperbolehkan. Sedangkan untuk mengetahui seberapa jauh contoh air tersebut disebut baik atau tidak dinilai dengan Metode Storet. Penentuan status mutu air dengan metode storet ini dimaksudkan sebagai acuan dalam melakukan pemantauan kualitas air tanah dengan tujuan untuk mengetahui mutu (kualitas) suatu sistem akuatik. Hasil analisis kimia percontoh air kemudian dibandingkan dengan baku mutu yang sesuai dengan pemanfaatan air (Matahelumual, 2007). Salah satu status mutu perairan yang baik yaitu parameter fisik dari air antara lain adalah rasa, bau, warna dan suhu. Kemudian parameter kimia diantaranya yaiu $\mathrm{pH}$, kesadahan, nitrat, nitrit, besi, flourida, sulfat, zat organik dan 
parameter biologi diantaranya Escherichia coli dan Total Coliform. Masyarakat dalam memenuhi kebutuhan air cendrung menggunakan air yang bersumber dari tanah karena air tanah dinilai masih relatif bersih, tercemarnya relatif kecil, dan suhunya relatif rendah. Menurut Sasrodarsono, dkk (1976:93) menyatakan, air tanah adalah air yang bergerak dalam tanah yang terdapat di dalam ruang-ruang antara butir-butir tanah yang membentuk itu dan di dalam retak-retak dari batuan yang terdahulu disebut dengan air lapisan dan yang terakhir disebut air celah (fissure water).

Menurut Soerjani dkk. (2005), kebutuhan akan air bersih oleh manusia semakin meningkat seiring dengan bertambahnya jumlah penduduk. Kenyataan yang terjadi sekarang ini, kualitas air semakin menurun serta mengalami penyimpangan tatanan sebagai dampak dari eksploitasi secara berlebihan dan perilaku mahluk hidup terutama aktivitas manusia yang tidak memperhatikan aspek lingkungan, sehingga tidak mencapai peruntukan dan mutunya bagi berbagai segi kehidupan. Penggunaan sumber mata air merupakan alternatif bagi daerah yang tidak mendapat pelayanan atau daerah yang tidak terjangkau PDAM. Banyak ditemukan penduduk yang bertempat tinggal di desa, dalam memenuhi kebutuhan air bersih untuk dikonsumsi memanfaatkan sumber air untuk memenuhi kebutuhan air minum.

Pemenuhan kebutuhan air minum bagi masyarakat di Desa Sanggalangit dilakukan dengan pengelolaan kelompok gotong royong dalam rangka menyediakan air bersih, selain itu sumber mata air di Pura Taman ini merupakan air yang disakralkan oleh masyarakat Desa Sanggalangit. Karena fungsi tersebutlah sumber mata air di Pura Taman Desa Sanggalngit sangat di jaga kesakralannya terbukti dengan di bangunnya pelinggih di sekitar sumber mata air. Meningkatnya aktivitas penggunaan lahan oleh penduduk di Desa Sanggalangit, seperti pertanian dan permukiman, maka dapat dipastikan hal tersebut akan mempengaruhi kualitas dari sumber air yang terdapat di Desa Sanggalangit. Selain itu, sumbermata air di Pura Taman yang berada dekat dengan lingkungan permukiman bisa tercemar akibat adanya pembuangan limbah-limbah rumah tangga.

Jumlah penduduk Desa Sanggalangit pada tahun 2001 awal dilakukan penelitian dan pemantauan kualitas air pada sumber mata air di Pura Taman yaitu sebanyak 3.804 jiwa dengankategori air yang layak digunakan khususnya dikonsumsi oleh masyarakat Desa Sanggalangit dan sekitarnya karena permukiman belum begitu padat dan lahan pertanian belum terlalu banyak (Badan Pusat Statistik Buleleng dalam Angka 2002). Data terakhir jumlah penduduk Desa Sanggalangit pada tahun 2018 adalah 4.496 jiwa (Badan Pusat Statistik Kecamatan Gerokgak dalam Angka 2018). Pertumbuhan penduduk yang semakin tahun semakin meningkat tentunya akan berdampak terhadap kualitas lahan lebih khususnya sumber air. Kualitas air pada sumber mata air di Pura Taman dipengaruhi oleh pertanian yang terdapat disekitar, keadaan pertanian tersebut akan mencemari sumber mata air dengan penggunaan pupuk yang berlebihan.

Masyarakat di setiap rumah juga memiliki hewan ternak seperti memelihara sapi dan babi untuk menambah penghasilan yang biasanya dikandangkan disekitar rumah, tentunya kotoran sapi dan babi yang tidak bisa diolah akan dibuang secara sembarangan ke selokan atau atau bahkan ditimbun begitu saja tanpa adanya 
pengolahan lebih lanjut, dengan kondisi seperti itu mengakibatkan air tanah akan tercemar oleh limbah khususnya kotoran sapi dan babi.

Berdasarkan permasalahan tersebut, sumber mata air di Pura Taman yang dipergunakan sebagai sumber air yang diperuntukkan untuk dikonsumsi dalam memenuhi kebutuhan masyarakat di Desa Sanggalangit perlu penelitian dan pemantauan lebih lanjut. Apabila ditemukan kualitas air yang dimanfaatkan atau dikonsumsi oleh masyarakat Desa Sanggalangit kurang baik tentunya akan berdampak kepada kesehatan masyarakat itu sendiri. Hal ini tentunya tidak diinginkan oleh masyarakat Desa Sanggalangit. Oleh karena itu, pemanfaatan air harus dilakukan dengan bijaksana disamping itu pula, kegiatan pengendalian kualitas maupun kuantitas air sangat perlu dilakukan untuk menjamin ketersediaan air bersih dan menjamin kualitas air yang akan dikonsumsi oleh generasi selanjutnya. Salah satu masyarakat Desa Sanggalangit yang memanfaatkan sumber air Pura Taman sebagai air minum.

\section{Metode}

Penelitian ini adalah penelitian deskriptif kualitatif dengan metode pengumpulan data observasi dan pencatatan dokumen. Penelitian deskriptif adalah penelitian yang dilakukan untuk mengetahui keberadaan variabel mandiri, baik halnya satu variabel atau lebih tanpa membuat perbandingan atau dengan menghubungkan dengan variabel lainnya (variabel mandiri adalah variabel yang berdiri sendiri). Lokasi penelitian ini berada di Desa Sanggalangit Kecamatan Gerokgak Kabupaten Buleleng. Sampel dalam penelitian ini adalah sumber mata air di Pura Taman yang berada di Desa Sanggalangit Jenis data yang digunakan dalam penelitian ini adalah Data sekunder berasal dari Dinas Pertanian Kabupaten Buleleng, Badan Pusat Statistik Kabupaten Buleleng dan Stasiun UPTD Balai Proteksi Tanaman Pangan dan Hortikultura Bali Laboratorium Hama Penyakit Tangguwisia serta sumber-sumber pustaka yang ada. Teknik pengupulan data dalam penelitian ini menggunakan observasi, pencatatan dokumen dan analisis laboratorium.

Kualitas air yang baik akan sesuai dengan peraturan yang dikeluarkan oleh pemerintah tersebut dengan kadar (konsentrasi) maksimum yang diperbolehkan. Sedangkan untuk mengetahui seberapa jauh contoh ait tersebut baik atau tidak dinilai dengan metode storet. Kualitas air dinilai berdasarkan ketentuan metode storet yang dikeluarkan oleh EPA (Environment Protection Agency, Canter, 1977) yang mengklasifikasikan mutu air ke dalam empat kelas, yaitu:

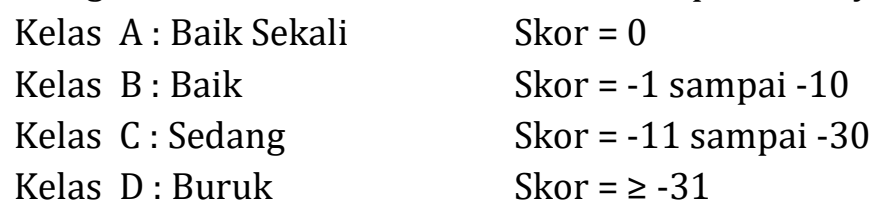

Cara Penilaian:

- Nilai negatif (-) diberikan bila hasil analisis melampaui atau tidak memenuhi syarat baku mutu;

- Nilai nol (0) diberikan bila hasil analisis memenuhi syarat baku mutu;

- Nilai parameter Bakteriologi = 3x nilai para-meter Fisika; 
- Nilai parameter Kimia = 2x nilai parameter Fisika;

- Bila angka rata-rata parameter hasil analisis melampaui baku mutu, diberi nilai $=3 \mathrm{x}$ nilai yang diberikan pada parameter maksimum atau minimum yang melampaui baku mutu;

- Jumlah percontoh dari suatu stasiun yang $\geq 10$, diberi nilai $=2 \mathrm{x}$ dari jumlah percontoh $<10$;

- Jumlah nilai negatif (-) seluruh parameter dihitung dan ditentukan status mutunya (tabel 1)dengan melihat skor yang didapat.

Metode storet dapat digunakan untuk menentukan baku mutu air berdasarkan wilayah atau satu titik (sumur) yang pengambilan percontoh airnya dilaksanakan berulang dalam kurun waktu tertentu.

\section{Hasil dan pembahasan}

\subsection{Kualitas Sumber Mata Air di Pura Taman di Desa Sanggalangit Sebagai Sumber Air Minum tahun 2019}

Kualitas air pada sumber mata air di Pura Taman Desa Sanggalangit pada tahun 2019 disajikan pada Tabel 1.

Tabel 1.

Kualitas air pada sumber mata air di Pura Taman Desa Sanggalangit pada tahun 2019

\begin{tabular}{|c|c|c|c|c|}
\hline Parameter & $\begin{array}{c}\text { Kadar } \\
\text { Maksimum yang } \\
\text { diperbolehkan }\end{array}$ & $\begin{array}{c}\text { Hasil } \\
\text { Pemeriksaan }\end{array}$ & Kualitas Air & Keterangan \\
\hline \multicolumn{5}{|l|}{ FISIK } \\
\hline Rasa & - & Tidak Berasa & Golongan A & Normal \\
\hline $8 a u$ & - & Tidak Berbau & Golongan A & Normal \\
\hline Warna & $15 \mathrm{TCO}$ & Tidak Berwarna & Golongan A & Normal \\
\hline Suhu & $\pm 3^{\circ} \mathrm{C}$ & $28^{\circ} \mathrm{C}$ & - & Normal \\
\hline \multicolumn{5}{|l|}{ Kimia } \\
\hline pH & $6,5-8,5$ & 6,5 & Golongan A & Normal \\
\hline Kesadahan & $500 \mathrm{Mg} / \mathrm{L}$ & $49,0 \mathrm{Mg} / \mathrm{L}$ & Golongan A & Normal \\
\hline Nitrat & $10 \mathrm{Mg} / \mathrm{L}$ & $0,00 \mathrm{Mg} / \mathrm{L}$ & Golongan $\mathrm{A}$ & Normal \\
\hline Nitrit & $1 \mathrm{Mg} / \mathrm{L}$ & $0,05 \mathrm{Mg} / \mathrm{L}$ & Golongan $\mathrm{A}$ & Normal \\
\hline Besi & $1 \mathrm{Mg} / \mathrm{L}$ & $0,1 \mathrm{Mg} / \mathrm{L}$ & Golongan A & Normal \\
\hline Flourida & $1,5 \mathrm{Mg} / \mathrm{L}$ & $0,21 \mathrm{Mg} / \mathrm{L}$ & Golongan $\mathrm{A}$ & Normal \\
\hline Sulfat & $400 \mathrm{Mght}$ & $62,5 \mathrm{Mg} / \mathrm{L}$ & Golongan $\mathrm{A}$ & Normal \\
\hline ZatOrganik & $10 \mathrm{Ng} / \mathrm{L}$ & $1,42 \mathrm{Mg} / \mathrm{L}$ & Golongan $\mathrm{A}$ & Normal \\
\hline \multicolumn{5}{|l|}{ Biologi } \\
\hline Escherichio Colit & $0 \mathrm{CPU} / 100 \mathrm{ML}$ & $20 \mathrm{CPU} / 100 \mathrm{NL}$ & - & Tidak Normal \\
\hline Totail Coliform & $50 \mathrm{CPU} / 100 \mathrm{ML}$ & $12 \mathrm{CPU} / 100 \mathrm{~N}$ & - & Normal \\
\hline
\end{tabular}

Berdasarkan Tabel di atas, maka dapat disimpulkan kualitas air pada sumber mata air di Pura Taman Desa Sanggalangit pada tahun 2019 yang ditinjau dari parameter fisik, parameter kimia, dan parameter biologi, ketiga parameter tersebut akan dijelaskan sebagai berikut.

a. Parameter Fisik

Pada parameter fisik berdasarkan pada penjelasan di atas, bahwa diketahui bahwa kualitas air pada sumber mata air di Pura Taman Desa Sanggalangit setelah diuji di UPTD Laboratorium Kesehatan Masyarakat Kabupaten Buleleng telah memenuhi standar baku mutu air yang ditetapkan pemerintah menurut parameter fisik. Dari segi warna, rasa, bau dan suhu secara rata-rata tidak melebihi kadar yang telah ditetapkan oleh pemerintah atau dapat dikatakan normal. 
b. Parameter Kimia

Pada parameter kimia berdasarkan pada penjelasan di atas, bahwa diketahui bahwa kualitas air pada sumber mata air di Pura Taman Desa Sanggalangit setelah diuji di UPTD Laboratorium Kesehatan Masyarakat Kabupaten Buleleng telah memenuhi standar baku mutu air yang ditetapkan pemerintah menurut parameter kimia. Hal ini dapat dibuktikan bahwa ph, kesadahan, nitrat, nitrit, besi, flourida, sulfat, dan zat organik secara rata-rata tidak melebihi kadar yang telah ditetapkan oleh pemerintah atau dapat dikatakan normal.

c. Parameter Biologi

Pada parameter biologi Berdasarkan penjelasan di atas, dapat diketahui bahwa kualitas air pada sumber mata air di Pura Taman Desa Sanggalangit setelah diuji di UPTD Laboratorium Kesehatan Masyarakat Kabupaten Buleleng tidak memenuhi standar baku mutu air yang ditetapkan pemerintah menurut parameter biologi. Hal ini dapat dibuktikan bahwa escherichia coli melebihi ambang batas yang ditetapkan oleh pemerintah berdasarkan PERMENKES NO. 32 TAHUN 2017 dan untuk total coliform tidak melebihi ambang batas yang ditetapkan oleh pemerintah berdasarkan PERMENKES NO. 32 TAHUN 2017.

\section{Tabel 2.}

Hasil Perhitungan metode storet

\begin{tabular}{|c|c|c|c|c|}
\hline No & $\begin{array}{l}\text { Parameter } \\
\text { Fisik }\end{array}$ & $\begin{array}{l}\text { Standar Baku } \\
\text { Mutu }\end{array}$ & $\begin{array}{c}\text { Hasil } \\
\text { Pemeriksaan }\end{array}$ & $\begin{array}{c}\text { Penentuan Sistem Nilai } \\
\text { Untuk Menentukan } \\
\text { Status Mutu Air }\end{array}$ \\
\hline 1 & Rasa & Tidak Berasa & Tidak Berasa & 0 \\
\hline 2 & Bau & Tidak Berbau & Tidak Berbau & 0 \\
\hline 3 & Wama & $50 \mathrm{TCU}$ & Tidak Berwama & 0 \\
\hline 4 & Suhu & $\pm 3^{\circ} \mathrm{C}$ & $28^{\circ} \mathrm{C}$ & 0 \\
\hline \multicolumn{4}{|c|}{ Klasifikasi status mutuair berdasarkan parameter fisik } & $\begin{array}{c}\text { Baik sekali sesuai baku } \\
\text { mutu }\end{array}$ \\
\hline No & $\begin{array}{l}\text { Parameter } \\
\text { Kimia }\end{array}$ & $\begin{array}{l}\text { Standar Baku } \\
\text { Mutu }\end{array}$ & $\begin{array}{c}\text { Hasil } \\
\text { Pemeriksaan }\end{array}$ & $\begin{array}{c}\text { Penentuan Sistem Nilai } \\
\text { Untuk Menentukan } \\
\text { Status Mutu Air } \\
\end{array}$ \\
\hline 1 & $\mathrm{Ph}$ & $6,5-8,5$ & 6,5 & 0 \\
\hline 2 & Kesadahan & $500 \mathrm{Mg} / \mathrm{L}$ & $49,0 \mathrm{Mg} / \mathrm{L}$ & 0 \\
\hline 3 & Nitrat & $10 \mathrm{Mg} / \mathrm{L}$ & $0,00 \mathrm{Mg} / \mathrm{L}$ & 0 \\
\hline 4 & Nitrit & $1 \mathrm{Mg} / \mathrm{L}$ & $0,05 \mathrm{Mg} / \mathrm{L}$ & 0 \\
\hline 5 & Besi & $1 \mathrm{Mg} / \mathrm{L}$ & $0,01 \mathrm{Mg} / \mathrm{L}$ & 0 \\
\hline 6 & Flourida & $1,5 \mathrm{Mg} / \mathrm{L}$ & $0,21 \mathrm{Mg} / \mathrm{L}$ & 0 \\
\hline 7 & Sulfat & $400 \mathrm{Mg} / \mathrm{L}$ & $62,5 \mathrm{Mg} / \mathrm{L}$ & 0 \\
\hline 8 & Zat Organik & $10 \mathrm{Mg} / \mathrm{L}$ & $1,42 \mathrm{Mg} / \mathrm{L}$ & 0 \\
\hline \multicolumn{4}{|c|}{ Klasifikasi status mutuair berdasarkan parameter kimia } & $\begin{array}{c}\text { Baik sekali sesuai baku } \\
\text { mutu }\end{array}$ \\
\hline No & $\begin{array}{r}\text { Parameter } \\
\text { Biologi }\end{array}$ & $\begin{array}{l}\text { Standar Baku } \\
\text { Mutu }\end{array}$ & $\begin{array}{c}\text { Hasil } \\
\text { Pemeriksaan }\end{array}$ & $\begin{array}{c}\text { Penentuan Sistem Nilai } \\
\text { Untuk Menentukan } \\
\text { Status Mutu Air }\end{array}$ \\
\hline 1 & $\begin{array}{l}\text { Escherichia } \\
\text { Coli }\end{array}$ & $\begin{array}{c}0 \mathrm{CFU} / 100 \\
\mathrm{ML}\end{array}$ & 20 & -3 \\
\hline 2 & $\begin{array}{l}\text { Total } \\
\text { Coliform } \\
\end{array}$ & $\begin{array}{c}50 \mathrm{CFU} / 100 \\
\mathrm{ML}\end{array}$ & 12 & 0 \\
\hline \multicolumn{4}{|c|}{ Klasifikasi status mutuair berdasarkan parameter biologi } & $\begin{array}{c}\text { Cemar ringankisaran }-1 \\
\mathrm{~s} / \mathrm{d}-10\end{array}$ \\
\hline
\end{tabular}

Pada hasil perhitungan menggunakan metode storet kualitas air pada tahun 2019 menunjukkan klasifikasi status mutu air berdasarkan parameter fisik yaitu baik sekali sesuai baku mutu dengan nilai 0 , kemudian berdasarkan parameter kimia yaitu baik sekali sesuai baku mutu dengan nilai 0 , sedangkan berdasarkan parameter biologi yaitu cemar ringan dengan kisaran $-1 \mathrm{~s} / \mathrm{d}-10$. 


\subsection{Kelayakan Sumber Mata Air di Pura Taman Desa Sanggalangit Sebagai Standar Baku Mutu Sumber Air Minum Berbasis Metode Storet}

Kelayakan sumber mata air di Pura Taman Desa Sanggalangit dapat diketahui dengan cara menghubungkan kualitas sumber mata air dengan standar baku mutu air yang ditetapkan pemerintah melalui PERMENKES NO. 32 TAHUN 2017 dan disempurnakan menggunakan metode storet untuk mengetahui status mutu air. Standar baku mutu air oleh pemerintah bertujuan untuk mengatur kadar zat terlarut yang di toleransi dalam air yang akan digunakan sebagai sumber air minum.

Berdasarkan hasil uji laboratorium yang didasarkan pada PERMENKES NO. 32 TAHUN 2017 dilihat dari parameter fisik dan parameter kimia dapat diketahui bahwa kualitas sumber mata air Pura Taman di Desa Sanggalangit setelah dilakukan pengujian di laboratorium telah memenuhi atau tidak memenuhi standar baku mutu air telah ditetapkan oleh pemerintah. Dari parameter fisik yaitu rasa, bau, warna, dan suhu secara rata-rata baik sekali sesuai baku mutu yang telah ditetapkan oleh pemerintah kemudian dilihat dari parameter kimia seperti $\mathrm{pH}$, kesadahan, nitrat, nitrit, besi, flourida, sulfat zat organik secara rata-rata baik sekali sesuai baku mutu yang telah ditetapkan oleh pemerintah sedangkan dilihat dari parameter biologi sumber mata air di Pura Taman Desa Sanggalangit layak atau tidak layak sebagai sumber air minum karena terdapat kandungan escherichia coli dan total coliform dalam sumber mata air di Pura Taman Desa Sanggalangit terdapat escherichia coli sebesar 20 CFU/100 ML ketetapan pemerintah yaitu $0 \mathrm{CFU} / 100 \mathrm{ML}$ ini termasuk kedalam status mutu air cemar ringan dan menunjukkan harus dilakukan pengolahan terlebih dahulu sebelum dikonsumsi. Kemudian total coliform sudah sesaui dengan ketetapan pemerintah. Dengan adanya bakteri escherichia coli pada sumber mata air di Pura Taman tersebut sebesar $20 \mathrm{CFU} / 100 \mathrm{ML}$ masih layak untuk dikonsumsi tetapi perlu adanya pengolahan terlebih dahulu sebelum.

\subsection{Perbandingan kualitas air pada sumber mata air di Pura Taman pada tahun 2001 dan 2019}

Tabel 4.

Perbandingan Kualitas Air Pada Sumber Matar Air Pura Taman Tahun 2001 dan 2019

\begin{tabular}{|c|c|c|c|c|c|}
\hline Paranter & $\begin{array}{c}\text { Matar } \\
\text { Masinum yarg } \\
\text { dicerodevon }\end{array}$ & $\begin{array}{c}\text { Fasil } \\
\text { Penesiosan } \\
\text { petarahu } 202\end{array}$ & $\begin{array}{c}\text { Hasil } \\
\text { Penailsann } \\
\text { padatshon } 219\end{array}$ & Kalitas air & Vetergrgn \\
\hline \multicolumn{6}{|l|}{ FGI } \\
\hline fass & - & Tidek Jerss & Tidekbersa & Golorgand A & Nornal \\
\hline Eas & - & Tidakfatou & Todek Betals & GolorganA & Norna \\
\hline Bina & 50700 & Tidaboenvara & TidekBevvama & Golongand & Nomas \\
\hline 5 shu & $\pm 3 \%$ & $D^{2} \mathrm{C}$ & $28^{4} \mathrm{C}$ & - & Nomal \\
\hline \multicolumn{6}{|l|}{ Émia } \\
\hline ph & $65-15$ & 7,2 & 6.5 & GolorąanA & Nome \\
\hline Eastaran & $500 \mathrm{kgl}$ & ONght & 4300/gh & Eolorgand A & Nomá \\
\hline Ntrat & 15Vhl & $0,06 \mathrm{lg} / 2$ & $0,000 \mathrm{Mel}$ & GolonganA & Nomal \\
\hline Nert & $1 \mathrm{Mg} / \mathrm{l}$ & $0,05 \mathrm{Ngh}$ & $0,06 \mathrm{Mg} /$ & Golorgand & Nornal \\
\hline Eesi & $1 \mathrm{Hg} / \mathrm{L}$ & $0,44 \mathrm{Ng}$ L & $0,1 \mathrm{Mg} / \mathrm{L}$ & Golorgand & Nomad \\
\hline Flourisa & $15 \mathrm{Ng} / \mathrm{L}$ & $\langle 0,01 \mathrm{Mg} / \mathrm{L}$ & 0,21Mgl & GolongunA & Morma \\
\hline Safan: & 45XNG/ & $1,74 \mathrm{Wg} / \mathrm{L}$ & $62.5 \mathrm{mg} /$ & Golorgand & Nonal: \\
\hline 2a:Oraik & 181gl- & $2,42 \mathrm{Wgh}$ & $1,4 \mathrm{mg} / \mathrm{g}$ & Golorąand A & Nomis \\
\hline \multicolumn{6}{|l|}{ Eislogit } \\
\hline Escherichiscai & DCRU,100M & 0 OOL/100M & 2000,10018 & - & 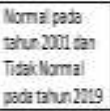 \\
\hline Totocolfent & 5Nop/1000 & OCPU/SOOM & $1200 / 100 \mathrm{M}$ & - & Noms: \\
\hline
\end{tabular}


Berdasarkan tabel di atas, maka dapat disimpulkan perbandingan kualitas air pada sumber mata air di Pura Taman Desa Sanggalangit pada tahun 2001 dan pada tahun 2019 yang ditinjau dari parameter fisik, parameter kimia, dan parameter biologi, ketiga parameter tersebut akan dijelaskan sebagai berikut.

\section{Parameter Fisik}

Pada parameter fisik berdasarkan pada penjelasan di atas, bahwa diketahui bahwa kualitas air pada sumber mata air di Pura Taman Desa Sanggalangit pada tahun 2001 dan pada tahun 2019 setelah diuji di Laboratorium tidak ada perbedaan baku mutu air yang ditetapkan pemerintah menurut parameter fisik. Dari segi warna, rasa, bau dan suhu secara rata - rata tidak melebihi kadar atau dapat dikatakan normal. Dikarenakan pengambilan sampel air pada saat kondisi iklim yaitu suhu di musim kemarau ini akan mempengaruhi zat kimia yang akan mengalami perubahan nilai proton dan elektron sehingga akan mempengaruhi kondisi fisik sumber mata air di Pura Taman Desa Sanggalangit.

\section{Parameter Kimia}

Pada parameter kimia berdasarkan pada penjelasan di atas, bahwa diketahui bahwa kualitas air pada sumber mata air di Pura Taman Desa Sanggalangit pada tahun 2001 dan pada tahun 2019 setelah diuji di Laboratorium telah memenuhi standar baku mutu air menurut parameter kimia tetapi masih ada perbedaan kadar disetiap zat. Dikarenakan adanya perubahan tetapi tidak terlalu signifikan karena disebabkan oleh curah hujan yang mengandung partikel yang masuk ke dalam air (Aerosol). Partikel yang masuk ke dalam air akan mempengaruhi $\mathrm{pH}$ air pada khususnya. Selain itu juga dipengaruhi oleh gerakan angin yang membawa nitrogen dan ammonia sedangkan kondisi sumber mata air di Pura Taman daerah yang melewati gunung sehingga gerakan angin yang membawa nitrogen dan ammonia akan menurun tajam menuju ke tempat sumber mata air di Pura Taman. Dan juga dipengaruhi oleh penggunaan pupuk urea pada pertanian di sekitar sumber mata air di Pura Taman Desa Sanggalangit. Bahan campuran pupuk urea adalah ammonia $\left(\mathrm{NH}_{3}\right)$. Kemudian penggunaan pestisida pada pertanian juga akan mempengaruhi sumber mata air di Pura Taman Namun kandungan seperti ph, kesadahan, nitrat, nitrit, besi, flourida, sulfat, dan zat organik pada tahun 2001 dan pada tahun 2019 secara rata - rata tidak melebihi kadar dapat dikatakan normal.

\section{Parameter Biologi}

Pada parameter biologi Berdasarkan penjelasan di atas, dapat diketahui bahwa kualitas air pada sumber mata air di Pura Taman Desa Sanggalangit setelah diuji di Laboratorium pada tahun 2001 telah memenuhi standar baku mutu air yang ditetapkan pemerintah menurut parameter biologi. Hal ini dapat dibuktikan bahwa escherichia coli dan total coliform secara rata-rata tidak melebihi kadar yang telah ditetapkan oleh pemerintah atau dapat dikatakan normal. Sedangkan pada tahun 2019 kualitas air 
tercemar dengan adanya escherichia coli dan total coliform pada air ini disebabkan oleh aktivitas masyarakat Desa Sanggalangit yaitu membuang limbah kotoran ternak, aktivitas MCK menjadi salah satu faktor adanya bakteri escherichia coli dan total coliform pada sumber mata air di Pura Taman.

\section{Simpulan dan saran}

Berdasarkan hasil analisis data dan pembahasan, maka dapat ditarik kesimpulan sebagai berikut. Hasil analisis kualitas sumber mata air di Pura Taman Desa Sanggalangit yang ditinjau dari sifat fisik dan kimia secara rata - rata baik sesuai dengan baku mutu menurut metode storet sedangkan ditinjau dari sifat biologi, status mutu air berbasis storet termasuk cemar ringan. Kelayakan sumber mata air di Pura Desa Sanggalangit sebagai standar baku mutu sumber air minum berbasis metode storet dengan standar pemerintah masih layak digunakan sebagai sumber air bersih tetapi harus dilakukan pengolahan terlebih dahulu sebelum dikonsumsi. Perbandingan kualitas air di Pura Taman Desa Sanggalangit pada tahun 2001 dan pada tahun 2019 pada parameter fisik masih sama dan sesuai dengan baku mutu air yang ditetapkan oleh sebagai sumber air minum, kemudian pada parameter kimia mengalami perubahan tetapi masih sesuai dengan baku mutu air yang ditetapkan oleh pemerintah sebagai sumber air minum sedangkan pada parameter biologi adanya perbedaan kualitas air pada tahun 2001 dan pada tahun 2019 yaitu pada tahun 2001 masih sesuai dengan standar baku mutu air yang ditetapkan oleh pemerintah sebagai sumber air minum, sedangkan pada tahun 2019 kualiatas air sudah tercemar dengan adanya escherichia coli dan total coliform pada air ini disebabkan oleh aktivitas masyarakat Desa Sanggalangit yaitu membuang limbah kotoran ternak, aktivitas MCK menjadi salah satu faktor adanya bakteri escherichia coli dan total coliform pada sumber mata air di Pura Taman.

Berdasarkan simpulan di atas, maka saran yang dapat diajukan dalam penelitian ini adalah sebagai berikut. Masyarakat Desa Sanggalangit diharapkan sebelum mengonsumsi sumber mata air di Pura Taman di sarankan untuk dilakukan pengolahan terlebih dahulu, karena masih terdapat kandungan escherichia coli dan total coliform pada sumber mata air di Pura Taman. Masyarakat Desa Sanggalangit diharapkan menjaga kondisi lingkungan dan memperhatikan lokasi tempat penampungan tinja (septik tank), tempat pembuangan sampah tidak berada didekat sumber mata air, sehingga pencemaran bakteri coliform tidak terus meningkat terhadap sumber mata air di Pura Taman. Pemerintah terkait diharapkan untuk memberikan kemudahan lebih pada masyarakat mengingat air PDAM merupakan alternatif termudah sebagai sumber air minum sehingga kesehatan masyarakat tidak menurun akibat mengkonsumsi air yang terdapat pencemaran didalamnya. Dan pemerintah Desa Sanggalangit agar selalu melakukan monitoring dan evaluasi kualitas air dengan dilakukan monitoring dan evaluasi kualitas air dapat mengetahui pencemaran yang terdapat pada air tersebut.

\section{Ucapan terimakasih}

Penelitian ini dapat diselesaikan berkat bimbingan dan dukungan dari berbagai pihak. Pada kesempatan ucapan terima kasih disampaikan kepada Rektor Universitas Pendidikan Ganesha, Dekan Fakultas Hukum dan Ilmu Sosial, Ketua Jurusan Pendidikan 
Geografi, Pembimbing Akademik, Pembimbing 1 dan 2, Penguji 1 dan 2, Staf dosen Pendidikan Geograf, dan rekan-rekan mahasiswa Jurusan Pendidikan Geografi angkatan 2015.

\section{Daftar Rujukan}

Arsyad, S. 1989. Konservasi Tanah dan Air. Bogor: IPB Press.

Arthana, I W. 2006. Studi Kualitas Air Danau Beratan, Buyan dan Tamblingan di Bedugul Bali. Jurnal Ilmu Lingkungan Ecotrophic.Vol.1, No. 2 (hal 34-38). Denpasar: Program Studi Ilmu Lingkungan, Program Pascasarjana, Universitas Udayana.

Atmaja, Dewa Made. 2004. Keseimbangan Air Danau Buyan dan Kebutuhan Air Bagi Masyarakat di Sekitar Desa Pancasari, Kecamatan Sukasada, Kabupaten Buleleng. Laporan Penelitian. IKIP Negeri Singaraja.

Atmaja, Dewa Made. 2018. Analisis Kualitas Air Sumur di Desa Candikuning Kecamatan Baturiti. Jurnal MKG. Volume 19, Nomor, 2 (hal 147 - 152). Singaraja: Fakultas Hukum dan Ilmu Sosial Undiksha dan IGI.

Atmaja, Dewa Made, MTH Sri Budiastuti, Prabang Setyono, Sunarto. 2016. Sediment Characteristics and Benthos Community Spread in Lake Beratan in Bali. Advances in Social Science, Education and Humanities Reseach, Volume 791 st International Conference on Geography and Education (ICGE).

Atmaja, Dewa Made. 2018. An ecohydrological-based management of Lake Beratan in Bedugul, Bali. IOP Conf. Series: Earth and Environment Science 148.

Esta, Kadek Ari. 2016. Penentuan Status Mutu Air Tukad Yeh Poh dengan Metode Stored. Dalam Jurnal Kimia. Volume 10, Nomor 1 (hal 65 - 74). Bali: Universitas Udayana.

Hendrawan, Diana. 2005. Kualitas Air Sungai dan Situs di DKI Jakarta. Jurnal teknologi. Vol.09, No.01 (hal 13 - 19). Jakarta: Universitas Trisakti. Tersedia pada laman www.ejournal.trisakti.ac.id/air/teknologi.pdf (diakses pada tanggal 29 Desember 2018).

Herlambang, Arie. 2006. Pencemaran Air dan Strategi Penangulangannya, JAI vol. 2 nomor 1. Peneliti Pusat Teknologi Lingkungan, BPPT.

Matahelumual, Bethy Carolina. 2007. Penentuan Status Mutu Air Dengan Sistem Storet di Kecamatan Bantar Gebang. Jurnal Geologi Indonesia.Vol.2, No. 2 (hal 113118). Bandung: Pusat Lingkungan Geologi.

Peraturan Menteri Kesehatan Nomor 32 Tahun 2017.Tentang Higiene dan Sanitasi

Saraswati, Sri Puji dkk. 2014. Kajian dan Sensitivitas Rumus Index PI, STORET, COME untuk Penentuan Status Mutu Perairan Sungai Tropis di Indonesia. Jurnal Manusia dan Lingkungan Vol. 21, No. 2 (hal 129-142). Yogyakarta. Universitas Gadjah Mada.

Sudarmadji. 2013. Mata Air: Perspektif Hidrologi dan Lingkungan. Yogyakarta: Sekolah Pascasarjana Universitas Gadjah Mada.

Sulistyorini, Lin Sumbada dkk. 2016. Analisis Kualitas Air Pada Sumber Mata Air Di Kecamatan Karangan dan Kaliorang Kabupaten Kutai Timur. Jurnal Hutan Tropis. Volume 4, Nomor 1 (hal 64-76).

Susana, Tjutju. 2003. Air Sebagai Sumber Kehidupan. Jurnal Oseana. Volume XXVIII, Nomor 3, (hal 17-25), ISSN 0216-1877. Jakarta: Pusat Penelitian OseanografiLIPI.

UPTD Balai Proteksi Tanaman Pangan dan Hortikultura Bali Laboratorium Hama Penyakit Tangguwisia 
Walukow, Aundry F. 2010. Penentuan Status Mutu Air dengan Metode Storet di Danau Sentani Jayapura Provinsi Papua. Dalam Berita Biologi. Volume 10, Nomor 3. Jayapura: Universitas Cendrawasih. 